\title{
Selected Reference Books of 1996
}

\section{Eileen Mcllvaine}

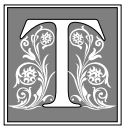

his article follows the pattern set by the semiannual series initiated by the late Constance M. Winchell more than forty years ago and continued by Eugene Sheehy. Because the purpose of the list is to present a selection of recent scholarly and general works, it does not pretend to be either well balanced or comprehensive. A brief roundup of new editions of standard works is provided at the end of the reviews. Code numbers (such as BE990) have been used to refer to titles in the Guide to Reference Books, 11th ed. (Chicago: ALA, 1996).

Although it appears under a byline, this list is a project of the reference departments of Columbia University Libraries, and notes are signed with the initials of one of the following staff members: Kathe Chipman, Barbara SykesAustin, Avery Library; Jim Coen, Business Library; Mary Cargill, Robert H. Scott, Sarah Spurgin, Junko Stuveras, Butler Library; Olha della Cava, Lehman Library; Nancy Friedland, Undergraduate Library.

\section{Religion}

The Oxford Encyclopedia of the Reformation. Ed. Hans J. Hillerbrand. New York and Oxford: Oxford Univ. Pr., 1996. 4 vols. \$450. ISBN 0-19-5-64933. LC 95-24520.

This admirable encyclopedia is surely destined to be the classic reference on its subject in English for decades to come.
The work of an editorial board headed by Hans J. Hillerbrand of Duke University and a multinational team of some 400 scholars, the Oxford Encyclopedia reflects new scholarly approaches to the Reformation which seek to place that set of events within a broader social, political, and cultural context; extend the chronological parameters of study well beyond the first half of the sixteenth century; and replace the traditional, narrow focus on Western European Protestant theology with an examination of a far wider range of creeds and popular religious practice, including analogous phenomena within Catholicism itself.

The result is a collection of 1,200 wellcrafted articles on a wide-ranging and comprehensive set of issues, from biographies of key leaders and theologians (including a number whose roles have long been underemphasized) and surveys of events in particular countries, regions, and cities to discussions of key doctrinal issues, creeds, and denominations and sketches of popular religious practice, from essays on relevant social, cultural, and political phenomena to a description of the development of Reformation studies. A measure of the inclusiveness of this study is its extensive coverage of the important, but all too frequently neglected Reformation history of East Central Europe, with ample discussion of affairs in Bohemia, Hungary, Transylvania, and Poland-Lithuania, as well as treatment of relations with and 
influence on the Orthodox world still farther to the east and south.

Recognizing that a variety of electronic bibliographic tools provide easy access to the broad range of historical literature, the editors have concentrated on pointing, in the brief set of citations that follow each article, to the best available literature on a given subject. Supplementing the text is a small set of useful maps, providing a sense of the spatial and quantitative extent of the Reformation. An unusually detailed and logically organized index significantly enhances access to the text, as do a liberal number of cross-references within the text. Finally, a synoptic table of contents, something lacking in far too many recent works of this kind, provides a useful overview to the geographical, chronological, and topical coverage found within the four volumes.

This is a "must-buy" item for any serious reference collection providing coverage of European history; and for smaller collections looking for a single work that can address the question of the Reformation, this is an obvious choice.R.H.S.

\section{Literature}

DCB: The Database of Classical Bibliography [computer file]. Atlanta: Scholars Pr., c1995. Annual. Computer laser optical discs: 4 3/4". \$340 for an institutional license; $\$ 85$ for individuals. LCC: sn 95-020503.

The first volume of the Database of Classical Bibliography is a computerized version of L'Année philologique, 1976-1987 (vols. 47-58; Guide BE990) which indexes scholarly work on ancient Greece and Rome from the period of the second millennium B.C. to about 800 A.D. Each entry is indexed by a number of elements: author, title, series, language (modern language of the text), place of publication, publisher, date of publication, as well as the page number, volume, ID number, rubrics, and topics used in the printed version of L'Année philologique. The user can also browse through the indexes of Thesaurus linguae Graecae Greek Genres (Guide BE1036), TLG Greek geographical origins, journal names, and a full-text word list. It is unfortunate that no effort has been made to standardize personal names both ancient and modern. The user is obliged to search various forms of names used in the course of years by the printed version and use truncation to retrieve both initial and full forms of given names. It also is possible to highlight a word in an entry and search the keyword using the cross-referencing function. Boolean and range searching and the Greek keyboard input are available.

Search results can be saved into a file, viewed, and edited using the "Query factor" function. An individual entry can be printed easily by clicking a printer icon or copied into a file by using the copy and paste feature of the Windows in a word-processing program. The "history" window shows various searches conducted during the current session.

The database in both Windows and Macintosh environments consists of one CD-ROM disk and a 122-page manual that accompanies the CD-ROM. The manual could be improved for the next edition which, we are promised, will include both updates and more retrospective coverage. It is really cumbersome to go through the manual in which each chapter alternates between Windowsand Macintosh-related explanations. The manual would have been easier to use if it had been divided into two parts by platform to facilitate a quick perusal. Although the manual is methodical, many key points the user should know are buried in the hundred-page overview. A quick reference card, such as the twopage summary of features supplied by many commercial database producers, would have been useful.

Another item on a wish list is some improvement in search software. It is not 
clear why some kind of relational database technique was not used to provide a complete bibliographical record each and every time the citation appears, instead of, like the printed version, using the cross-reference feature for all but the first entry. If you print a list of your hits, the printout does not give the complete information for the cross-referenced items. The window for the choice of bibliographic format also requires revision. The current version does not automatically cancel previous choices of format unless the user individually removes the check mark in a box. One can easily end up printing each citation in three different formats.

Although not without some reservations, the database is a necessary addition to university and research library collections that include substantial holdings in classical studies. The next issue was announced for publication in February 1997 and will cover volumes 45 to 60 (1974-1989) of L'Année philologique.-J.S.

\section{L'Europe des humanistes (XIVe-XVIIe} siècles)/répertoire établi par J.-F. Maillard, J. Kecskemeti, et M. Portalier. Documents, études, et répertoires (Institut de recherche et d'histoire des textes). [Paris]: CNRS; Turnhout: Brepols, 1995. 543p. ISBN 2-271-05376-5 (CNRS); ISBN 2-50350435-3 (Brepols).

The main section of Humanist Europe: A Bio-bibliographical Register of Textual Transmission 1300-1650 is an alphabetical list of humanists. Each entry provides name; dates and places of birth and death; profession; biographical sources; and the list of ancient and medieval works the humanist edited, commented on, or translated, with references to sources such as major library catalogs and printed bibliographies. Although preference is given to printed publications, some manuscript editions are included and so noted. What are not included are adaptations, imitations, and "the implicit transmissions" such as Petrarch's contributions in disseminating Plato's ideas. It is, therefore, as the title indicates, "textual transmission" including both manuscript tradition and printing. It recaptures a history of editions, but not a history of ideas. The indexes are to transmitted author and variant name of humanist and the volume ends with a bibliography of cited sources.

This work should be useful as a biobibliographical source as well as a starting point for the study of textual transmission in medieval and early modern Europe. Included among the 2,350 entries are a number of now-obscure humanists along with the more famous such as Erasmus, Petrarch, and Copernicus for whom more comprehensive bibliographies are available.-J.S.

Wells, Daniel A. The Literary Index to American Magazines, 1850-1900. Bibliographies and Indexes in American Literature, 22. Westport, Conn.: Greenwood, 1996. 441p. \$85. ISBN 0313-29840-8. LC 95-26447.

This is a companion and supplement to the compiler's Literary Index to American Magazines, 1815-1865 (1980, Guide BE420n). Though the dates overlap, the coverage does not, and the only journal I could find common to both was the North American Review. The new volume is an index to thirteen of "the most prominent magazines of the age that contain significant literary content" (Introd.), including Harper's, the Atlantic, Scribner's Monthly, for example. Though many have their own indexes,. Wells has examined each issue himself, making this an invaluable guide to nineteenth-century American views of literature.

The authors indexed, as well as some subjects (Women, Drama, Transcendentalism, etc.), are arranged alphabetically. Though the journals are American, the issues they discuss are broad, ranging from Shakespeare, Zola, Trollope to Darwin, etc. This is a major contribution to 
nineteenth-century literary studies. Frances Hodgson Burnett, for example, has dozens of entries in this index, compared with approximately twenty-five citations in the various volumes of the venerable Poole's Index to Periodical Literature (Guide AD282). The relatively small number of journals indexed means it is not a complete picture, of course; many of the book reviews listed for Burnett in the Combined Retrospective Index to Book Reviews in Humanities Journals, 1802-1978 (Guide BA7) are not in this index, though several additional ones are.

Unfortunately, the arrangement and explanations are somewhat opaque. The Introduction says each entry begins with an "alphabetical list of cited works and all references to them." There is no further explanation. Looking at the entries referred to does not make it clear whether this section contains citations to articles by or about the author. The occasional brief annotations in some cases suggest both, and the references have no titles.

After this cryptic list comes a list of books, some of which were originally published in magazines. Looking carefully at the entries, it appears that serial, which appears in some entries, refers to the serialization of the work listed and that rev refers to a review of it. After this list of individual titles, there are brief entries for articles, poems, and stories by the authors, with no titles, making identification a cumbersome and time-consuming process.

Presumably, the already high price would be driven even higher if space had been allowed for titles, but the compilation's convenience would have been increased even more. Even with its difficulties, however, this is essential for any library supporting American literature.-M.C.

\section{Women's Studies}

British Women's History: A Bibliographical Guide. Comps. June
Hannam, Ann Hughes, and Pauline Stafford. History and Related Disciplines: Select Bibliographies. Manchester: Manchester Univ. Pr.; New York: St. Martin's Pr., 1996. 150p. \$79.95. ISBN 0-7190-4652-1. LC 95-1038.

British Women's History is a selected bibliography intended primarily for faculty teaching women's studies courses or bringing women's history into existing courses; undergraduates working on papers and class projects; and those with an amateur interest in women's history. The material has been organized into three broad periods: c500-c1500, c1500-c1800, c1800 to the present. These periods are further subdivided by sections addressing family, health, sexuality, work, politics, prostitution, crime, witchcraft, religion, education, the arts, and autobiography.

This bibliography will be of some use to undergraduates, but it does a very poor job of referring to standard reference works on British women's history: Barbara Kanner's three-volume Women in English Social History (Guide CC607) is cited only for the third volume dealing with autobiographies, and is cited in a general section titled "Sources and Problems" rather than in the section on nineteenth-century autobiography. Some extremely useful bibliographies, including Linda Frey's Women in Western European History: A Select Chronological, Geographical, and Topical Bibliography (Guide DC5) are not even included. Most entries are not annotated, although some contain useful evaluative remarks. There is no subject index, but there are some crossreferences. Most readers at larger institutions will be better served by Historical Abstracts on Disc (Guide DA176n) and the International Medieval Studies Bibliography on Disc (see below), which duplicate virtually everything in this bibliography - with more comprehensive annotations.-S.S. 
Ryan, Barbara. The Women's Movement: References and Resources. New York: G. K. Hall, 1996. 339p. \$45.00. ISBN 0-8161-7254-). LC 95-46137.

This annotated bibliography focuses on the U.S. women's movement "and all that is attached to it. Thus, particular issues that the movement has fought for, ideological positions, theories, and the generalized spread of a feminist consciousness, schisms, divisions, and hotly debated issues within the movement and in the general society are all part of the changing dynamics of two centuries of feminist thought and activism in American society" (Pref.).

This is a useful bibliography that will be especially helpful to upper-level undergraduates. It focuses almost completely on secondary materials published since 1980. Five chapters address firstand second-wave feminism; women activists; feminist discourse; and issues relating to race, class, gender, work, pornography, politics, discrimination, religion, and antifeminism; and a final chapter presents a guide to primary sources. Most of the items cited can now be found in the America: History $\mathcal{E}$ Life database or the Women's Resources International CDROM (NISC, 1996), but the arrangement and introductory essays are helpful in framing the material. The final chapter, which has sections listing reference works, compilations of primary sources, and lists of library collections and archives, would have been even more useful had the author included citation to published descriptions and finding aids for these collections. -S.S.

Tovar Ramírez, Aurora. Mil Quinientas Mujeres en Nuestra Conciencia Colective: Cátalogo Biográfico de Mujeres de México. Mexico City, Mexico: Documentación y Estudio de Mujeres, 1996.767p. ISBN 968-6851-61-X.

This biographical dictionary includes more than 1,500 Mexican women born before 1925. Each entry provides a list of facts: birth and death dates (with places), the occupations for which the biographee is known, and citations to relevant secondary sources, followed by a biographical essay ranging from 100-300 words and a list of her writings (titles and dates only). The dictionary also includes a complete bibliography of the secondary works cited in the biographical entries and a name index.

This is an extremely useful reference work. It pulls together information from a variety of sources-encyclopedias, histories, biographical dictionaries, journal articles - and having a bibliography of all the secondary sources consulted will be very useful to students. The major flaw, which one hopes will be addressed in future editions, is the lack of an index by occupation: every woman has been assigned one or more professions (e.g., revolutionary, nurse, poet, novelist, professor), and readers would find it very useful to identify women by profession (even more valuable would be a profession index organized chronologically).S.S.

\section{Film Studies}

Film Researcher's Handbook: A Guide to Sources in North America, South America, Asia, Australasia and Africa. Comp. Jenny Morgan. London and New York: Routledge, Blueprint Book, 1996. 452p. \$35. ISBN 0-41515123-6.

The Film Researcher's Handbook is a reference guide to international film and video libraries, archives, and collections in five major continents excluding Europe. The work is intended for the film researcher as a tool for locating and obtaining visual material for film production, including feature film clips, newsreels, period shots, and sounding clips. Also included for reference is a short glossary of terms, procedures for film research, and information on copyright and licensing agreements. 
The handbook is arranged in three major sections. The first is by country, with an alphabetical listing of organizations. For each organization, pertinent information such as address, phone number, name of contact, subjects, and procedure and description of collection is provided. Inexplicably, for a number of entries, descriptive information is not included. The second section is arranged by topical subject, followed by a third section listing national archives. Supplemental indexes are intended for narrower subject searches, although this falls short. Not all cross-references are included, omitting many topics listed within the organization's description. Also provided is an index by organization and, lastly, a listing by country, with organizations listed alphabetically. The guide is useful for identifying organizations and archives in the continents specified, and is recommended for research collections and universities supporting programs in film studies and production.

For researchers interested in organizations and archives in Britain and North America, it is recommended to use the Researcher's Guide to British Film and Television Collections (Guide BH181) and Footage 89: North American Film and Video Sources (1989; Guide BH178), supplemented by Footage 91 (1991; Guide BH178n), both excellent and thorough works. - N.E.F.

\section{Art and Architecture}

Dictionary of Art. Ed. Jane Turner. New

York: Grove's Dictionaries, 1996. 34 vols. \$8,000. ISBN 1-8844-4600-0. LC 96-013628.

Arguably the most important art historical publishing event of the decade, this 34-volume work (also known as the Macmillan Dictionary of Art for its British publisher), incorporating 25 million words written by 6,700 contributors from 20 countries, has arrived to take its place (on over six linear feet of shelving) in art and academic libraries. A fourteen-year effort, the Dictionary of Art aims to fulfill the need for "an illustrated reference work that provide[s] comprehensive coverage of the history of all the visual arts worldwide, from prehistory to the present" (vol. 1, p. vii), thus superseding its only comparable predecessor, the Encyclopedia of World Art (Guide BF73). Modeled on its sister publication, The New Grove Dictionary of Music and Musicians (Guide BJ141), the Dictionary of Art will likely become the main source for art reference, particularly in libraries unable to acquire comprehensive collections, although priced at $\$ 8,000$, it may prove to be an economic hardship for those very libraries.

As expected, the major categories of signed articles include biographies (more than 20,000, but not exhaustive) of not only artists but also patrons, collectors, critics, and art historians (mostly deceased, although an admirable currency is shown in the entry for Meyer Schapiro, whose death on March 3, 1996, is noted); entries for cultural and ethnic groups, modern countries as well as ancient civilizations; cities with significant artistic traditions, archaeological sites, and important buildings; styles, schools, groups, and movements (500 entries); forms, themes, subject matter (e.g., marine painting, portraiture, etc.; 800 entries); materials and techniques (600 entries); and general topics in all fields of the visual and decorative arts, architecture, design, and photography (but not film).

Perusing (and using) the index in the last volume produces both pleasure and pain: the 750,000 entries to the 45,000 articles are arranged alphabetically letter by letter rather than word by word with spelling according to British usage, thus placing "Color Print Society" [U.S.] after "Colorado," but without any crossreference from "Color" to "Colour," where the main article and many subheadings for this subject are found. Other fine points of alphabetization and ordering should be checked in the introduc- 
tion in volume 1 for the treatment of such nuisances as saints' names in various languages, diacritics, acronyms, anonymous artists, foreign terms and transliterations, and other similar challenges to the art researcher.

The index is selective in its inclusion of individual works of art. Titles of paintings are not included, but many freestanding works (such as altars, sculptures, and buildings) are, with the result that the Laokoon can be found in the index, whereas The Last Supper cannot. Neither can Grant's Tomb, although other important memorials are listed. Each volume except the index begins with a list of general abbreviations and ends with a list of photo credits (nearly 20,000 illustrations are integrated throughout the text on every page of the dictionary). Other lists appear only in the appendices in volume 33, including locations (i.e., locations cited for an illustration, not a list of works of art with their locations), periodicals and reference works cited in the bibliographies at the end of each article, and a list of contributors. Because these are lists, not indexes, it is not possible, for example, to identify all the articles written by a given contributor, as only his or her name (without affiliation) has been given.

Although no single source can ever do it all, the Dictionary of Art quickly looks to become the reference tool of first choice for students, scholars, curators, collectors, and librarians well into the next century.-B.S.A.

Peterson, Andrew. Dictionary of Islamic Architecture. London and New York: Routledge, 1996. 342p. \$99.95. ISBN 0-415-06084-2. LCC 96-120478.

Among several interesting publications in the past decade on Islamic architecture is this encyclopedic dictionary, which is from the same publisher and in the same format as Gwendolyn Leick's Dictionary of Ancient Near Eastern Architecture (Guide BF243n). It is a welcome complement to K. A. C. Creswell's massive Bibliography of the Architecture, Arts, and Crafts of Islam . . . (Guide BF17).

Peterson worked to include the lesserknown Muslim cultures of Southeast Asia, India, East and West Africa, along with the Middle East and North Africa. He included vernacular architecture, viewing it as providing a context for the more famous monuments. Entries cover particular dynasties or historic styles, sites and buildings, regions, and building types. They range in length from a sentence to several pages and benefit from ample illustrations, particularly plans. Longer entries conclude with "further readings" which are primarily for English-language publications incorporating many journal citations. The volume also includes two simple maps and an index that lists names and topics mentioned within entries as well as the entries themselves. - K.C.

\section{Political Science}

New Handbook of Political Science. Eds. Robert E. Goodin and HansDieter Klingemann. Oxford and New York: Oxford Univ. Pr., 1996. 880p. \$75. ISBN 0-19-828015-7. LC 96-21871.

The New Handbook of Political Science does not replace the nine-volume classic in the field - the Handbook of Political Science (eds. Fred I. Greenstein and Nelson W. Polsby, 1975; Guide CJ53) but, rather, builds on it by surveying the developments in the field since publication of the original handbook in 1975. The compilers of the new handbook cover staple political science topics, such as political institutions, political behavior, public policy, political theory, and international relations, but do so from a contemporary political perspective, which incorporates such present-day concepts as pluralism, ethnicity, feminism, and new ideas about democratization. To accommodate new theoretical frameworks and methodologies, the compilers abandoned the old structure and gave their work a 
new organization: (1) The Discipline; (2) Political Institutions; (3) Political Behavior; (4) Comparative Politics; (5) International Relations; (6) Political Theory; (7) Public Policy and Administration; (8) Political Economy; and (9) Political Methodology. Each section begins with an overview and closes with an essay that reflects upon how newer developments correlate with older traditions. The New Handbook of Political Science has name and subject indexes.O.d.C.

\section{History and Area Studies}

Heyman, Neil M. Western Civilization: A Critical Guide to Documentary Films. Westport, Conn.: Greenwood, 1996. 244p. \$59.95. ISBN 0-313-28438-5. LC 95-35676.

Western Civilization: A Critical Guide to Documentary Films is a filmography of readily available works on the history of Western civilization beginning with prehistory through the post-World War II era. The purpose of this guide is to present "useful and critical reviews" (Introd.) to assist other educators in selecting visual supplements for the classroom. This is an ambitious project by Neil M. Heyman, a professor of history at San Diego State University.

Primarily, titles were selected based on availability as either a purchase or a rental from major film collections at universities such as Indiana University or Iowa State University, or commercial organizations. Further attention was given to popular titles or those works that have been around awhile and are thought to be most likely to be selected by instructors.

The critical review process considered, for example, how the documentary uses visual means to present historical events, the film's accessibility, and how differing interpretations of historical events are presented. Additionally, it is believed by the compiler that the film should stimulate discussion.
The guide is arranged chronologically beginning with prehistory and ending with post-World War II. Individual titles as well as series were considered. For each era, the number of titles included vary. For each title the following is provided: general descriptive information; a short summary that comments on the subject and quality; a letter grade ranging from A for excellent to D- for inferior; and finally a critical discussion of the film in terms of organization, scope, use of visual elements - highlighting strong and weak points. The short summaries are useful, although the adjectives used are often repetitive. The reviews are the author's opinions based on his idea that a good film is clear and succinct and that the use of visual means to show historical events helps with material that cannot be presented verbally.

The guide includes a subject index, which would better serve the reader if it referred to the title of the film rather than the page number, as well as series and title indexes. The guide is useful as a beginning collection of documentaries on Western civilization. The grading system is intended as a quick-reference source, although it is a little discouraging to find many titles with grades below B included. The guide is well intended and is a useful tool for college and university libraries that support curriculum on the history of Western civilization.-N.E.F.

\section{International Medieval Bibliography.} [computer file] Leeds, U.K.: International Medieval Institute; Turnhout: Brepols, 1996. Annual. CD-ROM: 43/4". $\$ 1,618.40$. LC sn 96-47046.

This long-awaited CD-ROM tool is one of the year's most important achievements in the field of reference publishing. A joint undertaking of the International Medieval Institute at the University of Leeds and Brepols Publishers, it provides enhanced access to a bibliography of the same name that has, in print format, been a mainstay of research in me- 
dieval studies since 1968 (Guide DA143). The print version currently provides access to 220,000 citations from more than 4,000 periodicals and more than 5,000 other publications in a wide range of languages. The first release of CD-ROM includes data from 1984 to 1993 only, but the production schedule calls for a continuing expansion of coverage, so that by 1999, the electronic version should provide full retrospective coverage and close to current coverage.

Two interfaces are available, providing a "guided" and a "free search." The former offers nine search fields corresponding to the sections into which the individual records are divided-Modern Author, Article (title), Publication, Issue, and Publication Year; five in all to support retrieval of known items. The others, supporting topical searches, are General Subject (corresponding to the broad subject headings used in the print version), Century (or range of centuries), and Keywords (an additional set of subject terms designed to provide more specific subject retrieval). Within each of the search fields, Boolean operators, truncation, and browsing of the index of headings are possible.

The "free" search screen provides just three fields: General Subject (which combines the Keyword, General Subject, Geographical Area, Modern Author, and Articles fields of the other interface), Century, and Publication Year. More useful, perhaps, would be a general keyword field including all of the above areas except Modern Author, as part of the first search screen. This would provide a more efficient and flexible search interface overall.

A variety of options for marking, sorting, and printing and downloading is an additional advantage of this electronic publication, which represents a great step forward, particularly given the large amount of work traditionally required by the semiannual format of the print publication. Networking to support access by more than one user at a time also is avail- able for an additional fee. The CD-ROM is well worth the expense for any library supporting research or advanced instruction in the medieval field. - R.H.S.

Kovtun, George I. Czech and Slovak History: An American Bibliography. Washington, D.C.: Library of Congress, 1996. 481p. ISBN 0-8444-0929-1. LC 96-20776.

Czech and Slovak History is a listing of English-language, predominantly American, books and articles on Czech and Slovak history from antiquity through the Soviet invasion of 1968. Divided into chapters, broad subject (description and travel, for instance), or chronological, several chapters have further broad subdivisions. Within each chapter, the entries are arranged alphabetically by author. Surprisingly, the table of contents lists the chapter names, not the subdivisions, so it is only through persistence (or chance) that the reader will find the section on the Munich Crisis, for example, well into the 1918-1939 chapter. This arrangement would not be such a problem if there were an adequate subject index, but (in a work issued by the Library of Congress!) there is only an author index. Important items can easily be overlooked. The "Biographies and Memoirs" chapter, for instance, has a section on Edvard Benês, listing works by and about him, with no indication that there are many more works by him in the chapter on World War II, and, one assumes, additional items about him, though the reader would have to look through the entire chapter to find them. The broad divisions also mean that it is only by chance that related items are found together; more common is the experience of finding, for example, a reference to Pan-Slavism before World War I in the chapter 1618-1914, followed by a reference to Bohemia in 1619. There is a great deal of useful information in this bibliography, though because it is limited to items in English, scholars will need to look further. But it 
is regrettable that it was not arranged and indexed with more care.-M.C.

Lerski, Jerzy. Historical Dictionary of Poland, 966-1945. Westport, Conn., and London: Greenwood, 1996. 750p. \$125. ISBN 0-313-26007-9. LC 9446940.

This compact, but rich volume is a welcome addition to the reference literature of European history, providing Englishlanguage readers with an extensive guide to the complexities of Polish history from its origins through the end of World War II. A foreword by Alexander Gieysztor, dean of Polish historians, underscores the significance of this contribution, the work of the late George Lerski, a historian already very well known for his work on Poland in the Second World War and Polish-Jewish relations (Guide DC471). (Editorial work, following his death in 1992, was completed by Piotr Wrobel and Richard Kozicki.)

The book contains approximately 2,100 brief, but substantive entries, identifying and describing significant personalities, places, institutions, organizations, movements, events, and issues in Polish history. Each article includes one or two references to other basic or popular works, when possible, in English, that provide further coverage of the topic. A bibliography at the end provides citations to approximately 200 books in English, and a detailed index enhances access to the material contained in the text. One small shortcoming to this otherwise fine volume is the absence of cross-references from most of the Polish names and acronyms of the many political organizations and parties covered here; readers seeking information on one of them may not always know the English translation of the group's name.

Comparisons are certain to be drawn to a volume of the same title by George Sanford and Adriana Gozdecka-Sanford, published just two years ago by Scarecrow Press (and reviewed in this col- umn). There are certainly a number of striking similarities between the two works, but some important differences as well. The chronological scope of the older volume is broader, reaching all the way up to the post-Communist period, but the number of topics covered is considerably smaller - only about 400 entries in the Sanford volume. An introductory survey of the country's history, a somewhat more extensive and broader-ranging bibliography, a chronology, and a list of organization acronyms also distinguish the older volume from Lerski's volume and enable the two books to complement rather than substitute for one another. However, a student of Polish history looking for a single information source would probably find the Lerski, with its much more extensive content, the better buy, even despite its lack of coverage of the postwar era.

The Lerski volume is an indispensable tool for any reader seeking quick basic information in English on Polish history, and given the wealth of useful information it contains, it can be a valuable addition to the collection of more advanced researchers as well. There is still a crying need, however, for a similar volume providing the same depth of coverage for the half-century of Polish history that has passed since the end of the Second World War.-R.H.S.

McIlwaine, John. Writings on African Archives. Published for the Standing Committee on Library Materials on Africa. London: Hans Zell, c1996. 279p. \$75. ISBN 1-873836-66. LC 962089.

The beginnings of this bibliography first appeared in the last two issues of Library Materials on Africa (1973) compiled by J. D. Pearson, with a supplement in the journal African Research E Documentation (1973), which also published a working version of the present bibliography beginning with volume 62 (1994). 
Writings on African Archives is a bibliography of "material written about archives and manuscript collections located within Africa as well as about African-related archives and manuscripts located outside Africa" (Pref.). In two parts, with the first covering books and articles that describe the organization of a specific archive or its actual holdings in Africa, plus such topics as archival theory, archival legislation, records management and development, the archival profession, education and training, and conservation. The second section concentrates on archives related to Africa located overseas in Europe, North and South America, and Asia. This second part supplements Guides to the Sources for the History of Nations (Guide DD38).

The emphasis is on archival rather than literary significance. Each entry gives the bibliographical citation, a brief annotation, and location. The name index covers authors, editors, series titles, and names of individuals and institutions whereas the subject index treats countries, types of archives, and broad topics. Altogether this is a useful guide for Africanists. -E.M.

\section{Technology}

\section{Biographical Dictionary of the History}

of Technology. Eds. Lance Day and Ian

McNeil. London and New York: Routledge, 1996. 844p. \$150. ISBN 0415-06042-7. LC 95-26250.

This biographical dictionary is a companion volume to the Encyclopedia of the History of Technology (ed. Ian McNeil. London and New York: Routledge, 1990. 1062p.). Thirteen hundred names have been selected from the encyclopedia, although the editors tried not to duplicate those already covered by the Dictionary of Scientific Biography (Guide EA176) and other standard sources; however, in some cases, the emphasis on technology inevitably caused double coverage. The primary emphasis is on Anglo-American science and technology in the nineteenth and twentieth centuries. The dictionary, however, includes earlier historical figures such as Ambroise Paré, Blaise Pascal, Peter the Great, Leonardo da Vinci, and Cai Lun, who is usually credited with the invention of paper (c105 A.D.).

Entries are arranged alphabetically by name. Each entry includes date and place of birth and death, family background, education, and contributions to science and technology, followed by a bibliography of works by and about the subject. Immediately after name and dates, a few lines in italics identify the person's area of expertise and major contribution to technology. The entries are indexed by subject area, such as aerospace, public utilities, and weapons and armor, as well as by the topics and personal names mentioned in the articles.

There are a few factual or typographical errors that somewhat diminish the credibility of the dictionary as a reference source. In the article on Ambroise Paré, Henry II should read Henry III. A part of Frank Lloyd Wright's Imperial Hotel, Tokyo, is preserved in the historic Meiji village, although the hotel was demolished and rebuilt. - J.S.

\section{New Editions and Supplements}

Several new bibliographies of early British imprints have been published that also will be of interest to scholars of religious history and colonial and revolutionary North America. English Catholic Books 1701-1800: A Bibliography, compiled by F. Blom et al. ([Aldershot, Hants., U.K.]: Scolar Pr.; [Brookfield, Vt.]: Ashgate [1996]; 356p. \$94.95) extends coverage of Allison and Roger's Catalogue of Catholic Books in English Printed Abroad or Secretly in England 1558-1640 (1956; Guide BC 388), Thomas H. Clancy's English Catholic Books 1641-1700 (Chicago: Loyola Univ. Pr., 1974.; rev. ed. Bookfield: Ashgate Publ., 1996; 230p. \$67.95), and Allison and Roger's The Contemporary Printed Literature of the English 
Counter-reformation (1989, 1994; Guide BC388), based on the Eighteenth Century Short Title Catalog (now called English Short Title Catalog and available as a separate database from RLG (see Guide AA681n). The volume cites all Catholic books written in English and published in England, Scotland, Wales, Ireland, the colonies, or abroad, and Catholic books written in languages other than English (mainly Latin and French) if published in England "or in territory officially regarded as England." For each title, locations are given as well as notes on the context and information on the author, editor, and/or translator. Three indexes are provided: proper names (including those cited in the notes); printers, publishers, and booksellers; and titles.

British Imprints Relating to North America 1621-1760: An Annotated Checklist, compiled by R. C. Simmons (London: British Library; Toronto: Univ. Toronto Pr., 1996. 395p. \$95) is a chronologically arranged bibliography of works by British authors (not included are publications of American authors in England). This compilation, too, was assisted by the availability of the ESTC database (Guide AA681n). Each entry includes notes referring to citations in other bibliographies of British publications for the period, such as European Americana (Guide AA404); Church, Catalogue of Books Relating to the Discovery and Early History of North and South America (Guide DB2); Sabin, Dictionary of Books Relating to America (Guide AA409). There are author and title indexes.

The fourth and final volume of the Catalogue of the Fifteenth Century Printed Books in the Harvard University Library, compiled by James E. Walsh (vols.1-3, 1991-1994; Guide AA224) covers books printed in France, the Netherlands, the Iberian peninsula, England, and Montenegro, Hebraica, and supplementary entries (1996. 330p. \$45. Medieval \& Renaissance Texts \& Studies, 150). The volume includes descriptions of 3,517 editions, including a supplement of books acquired by the Harvard Law School but not yet reported or cataloged. The indexes of authors/titles; editors/ translators/secondary works; printers and places; provenance; incunabula containing manuscripts; incunabula with identified bindings are to this volume only. The volume ends with concordances to Hain, Proctor, Goff, and Gesamtkatalog numbers (see Guide, pp. 26-28).

Announced are two cessations and one resumption. The Annual Obituary 1980-1993 (New York: St. Martin's Pr., 1981-1984; Chicago: St. James Pr., 1984-1994. Annual) ceased with 1994. But, more significantly, the quarterly $\mathrm{Na}$ tional Union Catalog Register of Additional Locations (Guide AA114) will cease at the end of 1996 due to the decline in the number of libraries that report holdings. Instead, many libraries are maintaining their holdings on the bibliographic utilities.

The Bulletin critique du livre français (Guide AA332) ceased publication with December 1992. Now the monthly has resumed with October 1995 at a cost of 1700 FF with about $400-450$ reviews in each issue.

The Dictionary of National Biography supplements (Guide AH226) cease with this volume covering 1986-1990, edited by C. S. Nicholls (Oxford: Oxford Univ. Pr., 1996. 607p.). Like its American equivalent, the Dictionary of American Biography (Guide AH62), a new series will begin shortly that will be a revision with additions. This volume of the DNB covers 450 people, from Bernard Ashmole, Sir Frederick Ashton, Jacqueline du Pre, Lawrence Durrell, to Sir Huw Wheldon and Wallis Windsor. The indexing is by occupation and, most helpful, there is the cumulative index to all the supplements, 1901-1990.

The Falks, Byron A. and Valerie R., are continuing their series Personal Name Index to the New York Times Index with the 
supplement for 1975-1993. Volumes 4-6, which complete this section, were published in 1996 (Sparks, Nev.: Roxbury Data Interface, 1996. \$86.75 each volume; for earlier series, see Guide AE108). One should note that this supplement adds "names previously missed or not yet published in the Times Index when the Personal Name Index first appeared" (Introd.).

The New Interpreter's Bible, which began publication in 1994 (see Guide BC174n), has issued volume 4 (Nashville, Tenn.: Abingdon, 1996. 1,287p.) covering the First and Second Books of Maccabees, John, Psalms, each assigned to a different scholar in the field. Of special interest in this volume is a lengthy essay on Hebrew poetry. The essay follows the pattern in volumes 1 and 8, which have general articles (and short bibliographies) on the Old and New Testaments.

The editors of the Encyclopedia of Islam (Guide BC503) are to be commended for the assistance they are giving scholars and reference librarians by producing interim indexes. The newest ones are the Glossary and Index to Technical Terms to Volumes I-VII and to the Supplements Fascicles 1-6, compiled by J. van Lent and H. U. Qureshi (Leiden: Brill, 1995. 308p.), the Index of Proper Names to Volumes I-VIII and to the Supplements 1-6, compiled and edited by E. von Donzil (1996. 412p.), and the Index of Subjects to Volumes I-VIII and to Supplements, Fascicles 1-6, compiled by P. J. Bearman (1996. 272p.). The Glossary and Index is a first edition and indexes references to terms given their own entry as well as scattered throughout the text, "provided they were accompanied by a clear definition; where given, the language of origin, and of use, and when possible, the etymology of the term is listed in brackets following the entry" (Pref.). Of course, all three indexes give "reference to the appearance in the Encyclopedia." The name and subject indexes were divided in 1991 and, thus, the Index of Proper Names is an updating of the 4 th edition, 1993, whereas the subject index updates the 2nd edition, 1994.

Peter Bondanella's Dictionary of Italian Literature (1979; Guide BE1298) has appeared in a revised and expanded edition (Westport, Conn.: Greenwood, [1996]. 716p. \$99.50). The number of entries has grown to 400 with new contributors, and particular attention has been paid to updating the bibliographies. Of special interest are the new articles on Italian film, Italian art, feminism, postmodernism, and various contemporary authors. The time line has been extended to 1995, with Antonioni receiving the Oscar to commemorate his entire career.

The third, enlarged edition of the Index to American Photographic Collections, compiled at the International Museum of Photography at George Eastman House, edited by Andrew H. Eskind (New York: G. K. Hall, 1995, c1996. 1058p. \$165) follows closely the format of the 1990 edition (Guide BF344). It covers 582 collections, as compared to 535 in the second edition, and the work of 66,830 photographers, as compared to 32,465 ; the latter section also indexes photographers featured in several thousand exhibition catalogs. The inclusion of the fax number for each collection is a useful addition.-K.C.

Jack Robertson's Twentieth Century Artists on Art: An Index to Writings, Statements, and Interviews by Artists, Architects, and Designers, revised and enlarged (New York: G. K. Hall, c1996. 834p. \$95), has the same scope as the first edition (Guide BF145) but includes "a significantly higher proportion of entries for architects, landscape architects, commercial and industrial designers, and craftsmen in all media" (Pref.). There are nearly twice as many citations, covering 14,400 artists, rather than 5,000, from 1984 to early 1995. A similar work, covering artistic movements since 1945, uses a chronological arrangement for about 250 artists-Theories and Documents of Contemporary Art: A Sourcebook of Artists' Writ- 
ings, edited by Kristine Stiles and Peter Selz (Berkeley: Univ. of California Pr., c1996. California Studies in the History of Art 35. 1003p. \$60). - K.C.

Einar Lauritzen and Gunnar Lundquist developed a title listing of some 33,664 films-American Film-Index 1908-1915 and 1916-1920 (Guide BH189). Paul Spehr has compiled an index to the indexAmerican Film Personnel and Company Credits, 1908-1920: Filmographies Reordered by Authoritative Organization and Personal Names from Lauritzen and Lundquist's American Film-Index (Jefferson, N.C.: McFarland, [1996]. 696p. \$110). Spehr has indexed each film by name of the film company, person who worked on the film (e.g., animator, art director, camera operator, director, producer, cast member, composer), title of the book, play, story, poem, or song adapted for the movie. The appendix gives the alternate titles, and there are copious cross-references.

One of the most exciting revisions to appear is the third edition of the Oxford Classical Dictionary, edited by Simon Hornblower and Antony Spawforth (Oxford and New York: Oxford Univ. Pr., 1996. 1640p. \$75; 2d. ed., 1970. Guide DA103). The work of 364 scholars, the 6,250 contributions make the volume 30 percent larger. The articles with their bibliographies have been updated to reflect the state of scholarship 1990-1994. See the List of New Entries at the front of the volume, but many more entries have been changed.

The seventh edition of the Encyclopedia of American History, edited by Jeffrey B. and the late Richard B. Morris (New York: HarperCollins, 1996. 1278p. \$55.00; 6th ed. 1982. Guide DB44) is updated to the end of December 1993. There has been some reorganization of the topical section.

Another standby for American studies researchers is the Encyclopedia of American Biography, compiled by John A. Garrity and Jerome Sternstein (1974; Guide AH60n), which focuses on the "most important and significant historical actors in American history . . . chosen because of their influence on history and not because of their current celebrity" (Introd.), with factual information and interpretive essays. The second edition (New York: HarperCollins, 1996. 1263p. \$50) has added 93 new names and reevaluated many of the other entrants, especially the last four presidents and those who died since 1974 . No one seems to have been dropped.

Richard B. Matchette has revised and expanded the Guide to Federal Records in the National Archives, superseding the Guide to the National Archives of the United States (Guide DB38) to be current as of September 1, 1994 (Washington, D.C.: NARA, 1996. 3 vols.). Like the earlier editions, each chapter covers a record group and the administrative histories include, though in outline form, establishment date, predecessor and successor agencies, related records, finding aids, any inclusion of other media, subject access terms, references to microfilm publication. Volume 3 is an extensive index to all personal names, all acts of Congress, name of organizations, place names, and topics drawn from the subject access terms.

Greenwood has been producing dictionaries of specific wars such as the Spanish Civil War (1982; Guide CD517), the Korean War (1991; Guide DE215), and of specific periods of a country's history such as the Spanish Empire (1992; Guide DC515), Modern Spain (1990; Guide DC514; also see below for England). The Historical Dictionary of the Spanish American War by Donald Dyal (Westport, Conn.: 1996. 378p. \$89.50) follows the pattern: signed articles on people, organizations, events, with short bibliographies ending many of the entries, detailed chronology, extensive cross-references, bibliographical essays. Dyal points out the need for new interpretations as "recent scholarship has looked at the Spanish American War, its after- 
math and implications for the 20th century in fresh light" (Introd.).

Like its predecessor for Tudor England (Guide DC322), the Historical Dictionary of Stuart England, 1603-1689, edited by Ronald H. Fritze and William B. Robeson (New York: Greenwood, 1996. 611p. \$95) offers signed articles from about eighty scholars on "political and religious history although important cultural, social, economic and intellectual topics have been included" (Introd.). Each article includes a short bibliography; cross-references are marked with an asterisk. The volume ends with a chronology, a classified bibliography (fourteen pages) of recent books, and a subject index.

The Bibliography of British History, 1914-1989 was compiled by a single scholar, Keith Robbins (Oxford: Clarendon Pr., 1996. 918p. \$160. For earlier volumes, see Guide DC270). The focus is on "Britain itself and to regard internal development of overseas possessions and self-governing territories as largely extraneous" (Pref.). Coverage of Scotland and Wales is within the relevant subject, not as separate sections; otherwise the arrangement is similar to the earlier volumes. A paragraph begins each chapter defining the scope of the section. Only published works are cited-monographs, articles, series and serials, government documents. The index is to author and title only, so readers must look for relevant sections through the table of contents.

Benjamin Núñez has completed the Dictionary of Afro-Latin American Civilization (Guide CC387) with volume 2, From Ancient Kings to Presidents (New York: Greenwood, 1996. 478p. \$110). The author admits that "much of the interaction has been extensively chronicled," but goes on to explain that "virtually all this rich literature is in Portuguese, a language most inaccessible to English speakers" (Introd.). Volume 1 (1994) treated "history, geography, religion, culture, trade, and politics" (Introd.) whereas volume 2 covered "some of the innumerable people, African and American . . . over their years of contact concentrating on the period from the conquest of Ceuta in 1415 to 1975 , when Portugal's colonies became independent of European rule." So this volume is strongly biographical with many entries giving the accomplishments but little background. "The source citations that follow an entry are keyed to the reference in the bibliography on pp. 471-78" (Publisher's Note).

For a number of years, Scarecrow Press has been publishing historical dictionaries for various countries with entries for personal names, places, and events; a chronology; and a bibliography - and compiled by a scholar. The quality has improved through the years and the volumes are now extremely useful. Some new volumes have appeared on the scene: Alan J. K. Sanders, Historical Dictionary of Mongolia (317p. \$54.50. Asian Historical Dictionaries, no.19); Surjit Mansingh, Historical Dictionary of India (511p. \$78; Asian Historical Dictionaries, no.20); Robert Stallaerts and Jeannine Laurens, Historical Dictionary of the Republic of Croatia (341p. \$45; European Historical Dictionaries, no.9); Leopoldina Plut-Pregelj and Carole Rogel, Historical Dictionary of Slovenia (345p. \$67; European Historical Dictionaries, no. 13). Of great interest are the latter two as there is so little in English. 